\title{
EVALUATION OF CO-COMPOSTED FAECAL SLUDGE APPLICATION IN AGRICULTURE
}

\author{
RAMAKRISHNA GIRIJA, NITHIN A. SHETTIGAR, \\ VENKATASWAMY RAMASWAMY RAMAKRISHNA PARAMA \& SHAMANNA GAGANA \\ Consortium for DEWATS Dissemination Society, India
}

\begin{abstract}
Water scarcity, increasing cost of inputs and poor soil quality are major reasons for decreasing agricultural productivity in India. It is therefore critical to optimize soil organic matter, which is vital for enhanced soil quality to improve productivity. Considering that some of the organic sources like farmyard manure, crop residues, green manure, etc. are dwindling as well as the negative implications of chemical fertilisers, we need to consider alternative sources. In this context, a study was conducted to evaluate the application of co-composted faecal sludge (FS) as an alternative; and to provide scientific evidence through field experiments about the potential for co-compost application in agriculture. An agricultural trial was conducted for two cropping seasons. The co-composted FS was one of the nutrient sources used in the trial. Nutrient-balanced final co-compost was produced as faecal sludge is rich in nitrogen; municipal wet waste is rich in carbon content. Randomised Block Design method was followed, and the application of five treatments with four replications per treatment was undertaken. Treatments comprised four types of nutrient sources - namely, treated faecal sludge, cocomposted FS (co-compost), farmyard manure, chemical fertilizers and control. The findings of the study showed that the yield obtained from crops grown under co-composted FS was higher than the other four treatments. The parameters for crop growth and development were better for co-compost applied crops. Further, the produce grown under co-composted FS was free from pathogen contamination. The study showcased the potential of co-composted FS as a nutrient source vis-à-vis other sources considered for the trial. The study showed that reusing co-composted FS in agriculture can benefit the farming community by enhancing soil productivity there by increasing crop yield. The study also highlights the need for further research to assess the impact of co-composted FS application on crop nutrient content and weed menace.
\end{abstract}

Keywords: co-composted faecal sludge, agriculture, soil productivity, agricultural trial.

\section{INTRODUCTION}

The current situation of agriculture in India is characterized by water scarcity, increasing cost of inputs, nutrient deficiency and poor soil quality - all of which is leading to decreased agricultural productivity. Despite the growing use of fertilizers, the country is experiencing stagnation in agricultural productivity and degradation of soil quality [1]. It is, therefore, critical to improve soil productivity to meet growing food demand with decreasing cultivable land. Organic matter is vital for good soil productivity as it improves physical, chemical and biological properties of soil, therefore, referred to as "Life of Soil". Organic matter sources are dwindling resulting in search for alternate sources [2]. The most common organic matter sources are farmyard manure, crop residues, vermicompost, urban waste etc. Humanure (compost from human faecal material and urine) could also be considered as an alternate organic matter source; however, the main concern is the health risks associated with reuse. This can be mitigated by adopting protection measures, which include not just treating human waste but also combining treatment with other measures like selecting suitable crops, using safety gear to control human exposure and safe cooking practices [3]-[5]. The WHO 2006 Sanitation Safety Planning process provides reuse of wastewater, excreta and grey water, which would help mitigate the risks associated with human waste application in agriculture. 
The use of human waste on farmlands is not a new concept. Farmers have been recycling human excreta by applying it on agricultural fields for centuries, which closes the nutrient loop by mimicking nature - nutrients move from soil into living organisms through the intake of food and are subsequently recycled back to the physical environment by excreta application onto farmlands. However, with the introduction of water-borne sewage and due to unsafe disposal of faecal sludge and wastewater into the environment, this nutrient cycle, and in turn, the water cycle too is interrupted and replaced by a linear system that transports nutrients away from soil and into water bodies. This leads to the deficiency of nutrients in soil and accumulation of nutrients in aquatic ecosystems.

Though there are benefits of FS use with respect to crop yield and soil fertility, some health issues have also been reported after working with FS [6]. The main reason may be the viable helminths in FS despite a long drying period [7]. Hence it is important to ensure that farmers are educated regarding safe reuse practices during application. Further, there is a need for research to assess the effect of long- term application of FS on farmer/consumer health and the environment and the impact of FS application on crop growth, yield and quality in comparison with other soil conditioners [8].

In this context, a study was conducted to evaluate the application of co-composted FS as an alternative to soil conditioners (e.g. faecal sludge, farmyard manure, chemical fertilizers) in peri-urban settings; and to provide scientific evidence through field experiments about the potential for co-compost application in agriculture. The study was conducted at the Faecal Sludge Treatment Plant (FSTP) in Devanahalli, Bengaluru (Fig. 1), in order to recover and reuse the nutrients from treated FS to agriculture in nearby farmlands, thereby closing the nutrient loop with minimum environmental footprint.

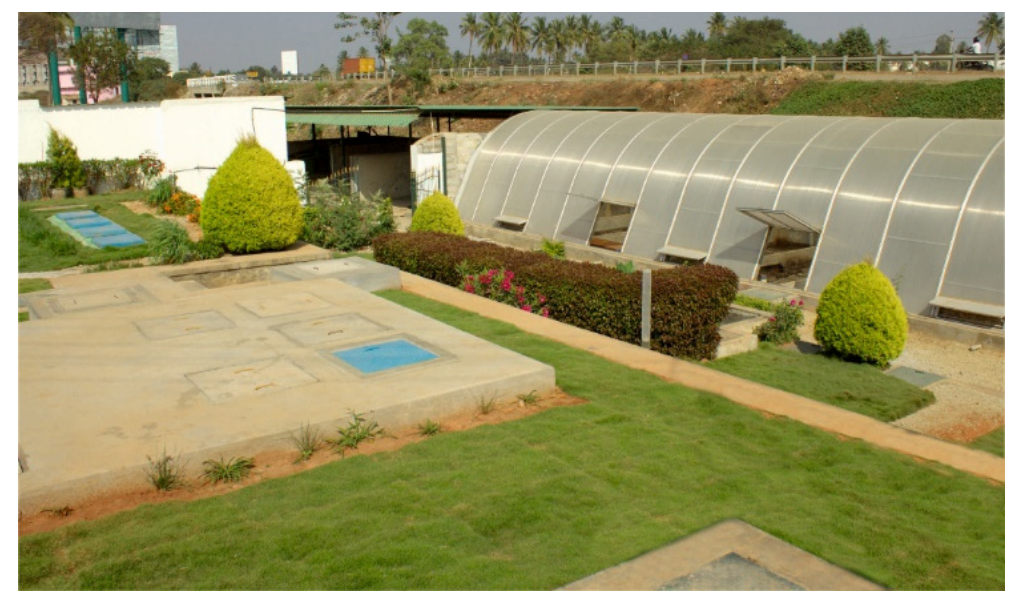

Figure 1: Faecal Sludge Treatment Plant (FSTP), Devanahalli, Bengaluru, Karnataka, India.

There are many studies conducted worldwide that quantify pathogen reduction achievable by various health protection measures for reuse of human waste. But lesser attention is paid to the impact of its long-term application in agriculture. This study, conducted by an agricultural trial with two cropping seasons, therefore aims at assessing the impact of co-compost application in comparison with other treatments/nutrient sources like faecal sludge, farmyard manure, chemical fertilizers and control on crop growth and development and yield parameters. 


\section{CASE STUDY ON SAFE REUSE OF CO-COMPOSTED FAECAL SLUDGE IN AGRICULTURE AT DEVANAHALLI, BENGALURU}

Devanahalli near Bengaluru became the first town in the country to get a first-of-its-kind town-scale faecal sludge treatment plant (FSTP) for the safe treatment and disposal of sludge collected from septic tanks and pit latrines. The plant is capable of treating human night soil without any human interference in an environment friendly and cost-effective manner. There is neither underground sewerage connection nor any organized septage treatment facility in the area which leads to washing of septage into existing open drains. Therefore, the faecal sludge treatment plant was setup. It was set up by Consortium for DWATS Dissemination (CDD) Society in collaboration with Devanahalli's Town Municipal Cooperation (TMC). The FSTP provides a safe delivery point for the waste. The objective of this project is to establish a pilot independent septage treatment unit and treat it to prescribed standards. The plant is successfully handling $100 \%$ of the sludge collected in Devanahalli today. The farmers in and around Devanahalli (Karnataka, India) have been using untreated FS on their farmlands. While FS is rich in nitrogen and moisture, there is a risk of pathogen contamination of the soil and crops. The main objective of the trial was to understand the effect of different treatments like faecal sludge, co-compost, farmyard manure, chemical fertilizers/recommended dose of fertilizers (RDF) and control on crop growth, development and yield parameters. A study was carried out at the Devanahalli FSTP site by CDD Society in collaboration with University of Agricultural Sciences, Bengaluru, to test the yield quality and quantity as well pathogen activation in co-composting of FS with Municipal Wet Waste (MWW). The premise available near the co-composting unit was used for undertaking field trials using different crops.

\subsection{Materials and methodology}

MWW was collected from households, hotels, and the vegetable market of Devanahalli town. Cesspool vehicles dislodge FS from septic tanks or soak pits and transport it to the town's FSTP. The FS undergoes an anaerobic treatment process and is laid onto drying beds. The FS slurry dries under sunlight, during which some pathogens get deactivated due to UV rays; but harmful pathogens like helminths eggs, E. coli, and faecal coliforms may still persist. These pathogens are then eliminated by co-composting of FS with MWW producing nutrient balanced co-compost/humanure, which is one of the inputs used for the field experiment conducted in the study area. The method of composting was by windrow method of co-composting dewatered faecal sludge (FS) with organic solid waste in 1:2 ratio (Fig. 2) to eliminate pathogen contamination [9].

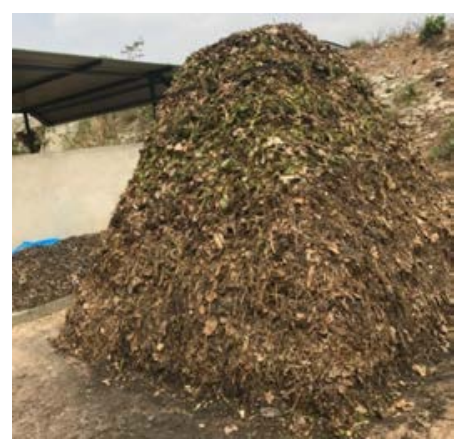

Figure 2: Windrow method of co-composting faecal sludge with municipal wet waste. 


\subsubsection{Field experiments - Randomised Block Design}

Under the study, a field experiment was conducted by an agricultural trial with a cropping season of field beans (Vicia faba) followed by sweet potato (Ipomoea batatas). Randomised Block Design (RBD), the standard design for agricultural experiments where similar experimental units are grouped into blocks or replicates (homogeneous experimental units), was followed. Treatments are then assigned at random to subjects in the blocks - once in each block. Through maximizing intra-block variation and minimizing inter-block variation, spatial effects in field can be accounted for in RBD. The defining feature of the Randomized Complete Block Design is that each block sees each treatment exactly once [10].

The total number of treatments decided was 5 with 4 replicates (Fig. 3). The field experiment was conducted for two cropping seasons ( 1 monsoon and 1 winter season).

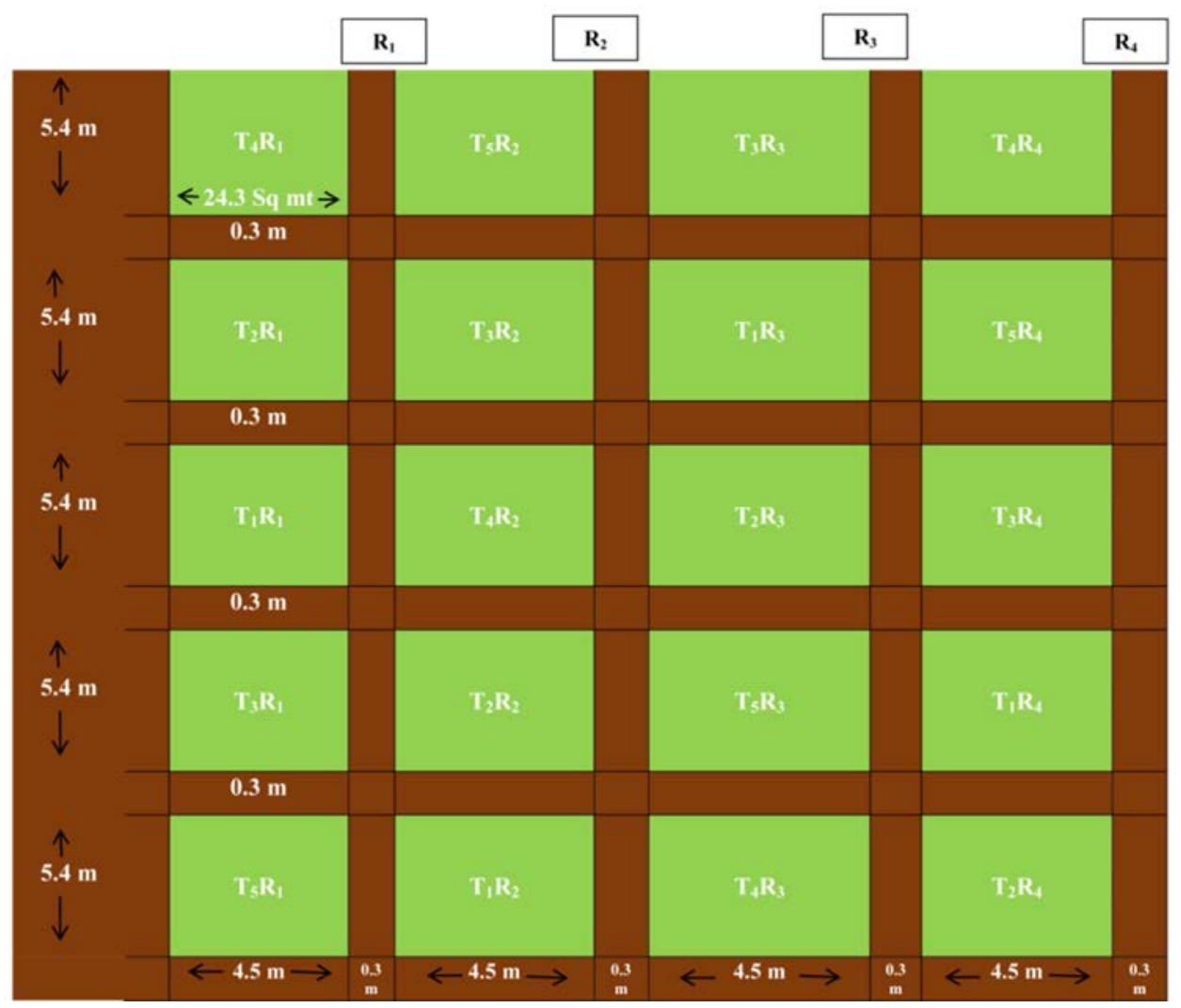

Figure 3: Randomised Block Design set-up.

The field trial included cultivating two crops - Field bean during Kharif season followed by sweet potato during Rabi season (see Fig. 4). Field bean is a high growing crop, which grows above the ground and the edible parts will not come in contact with humanure. Sweet potato is a root crop in which the edible parts will come in contact with the humanure applied. Preliminary analysis included testing soil samples for the physical, chemical and microbial parameters before starting cultivation in the field. Different organic sources used in the trial were also analysed for their nutrient content. 


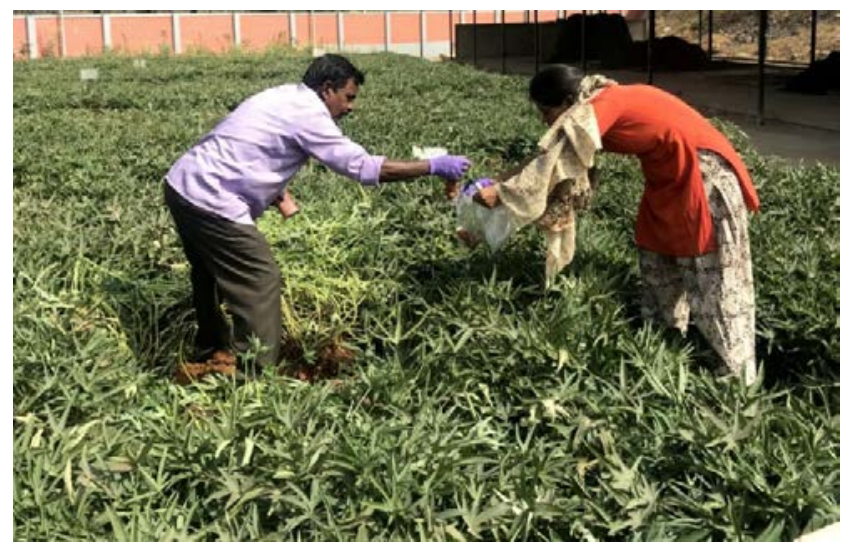

(a)

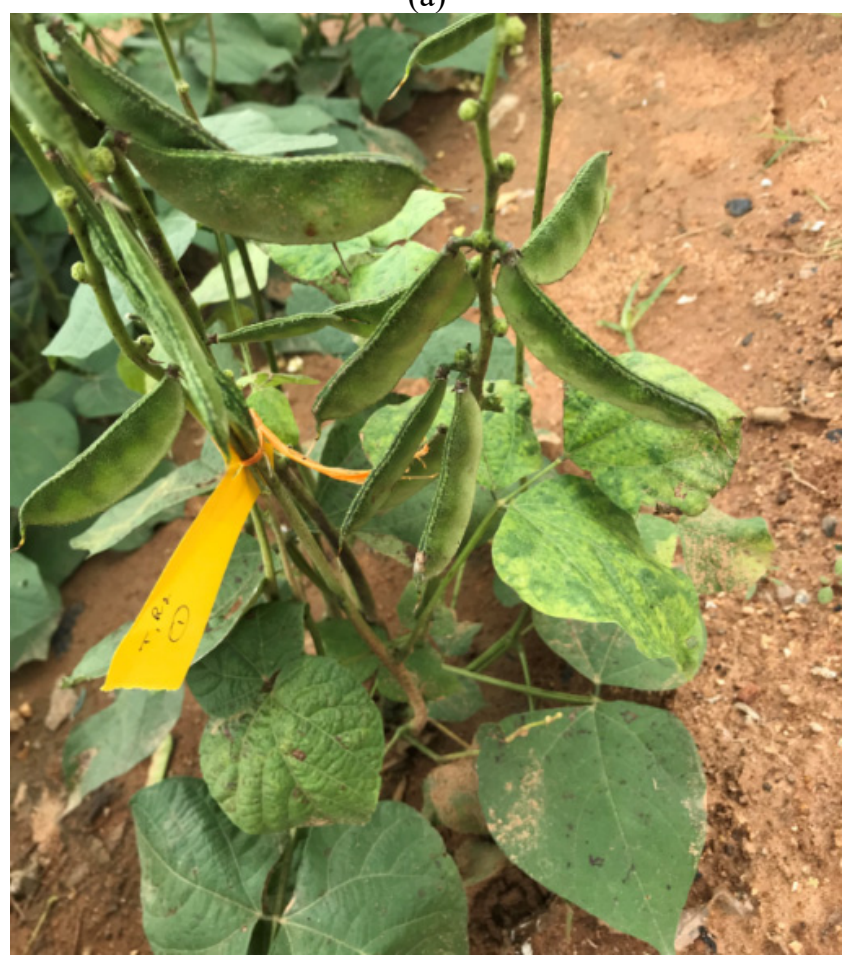

(b)

Figure 4: (a) Second crop, sweet potato - field experiment at Devanahalli; and (b) First crop, field beans - tagged plant in the field.

The nutrient requirement of field bean was calculated by taking into account the soil nutrient content, recommended dose of fertilizer for field bean (POP) and the nutrient content of the treatments/organic sources used in the experiment. The entire requirement of Nitrogen (N) was provided through organic sources like faecal sludge, co-compost and farmyard manure (FYM) for T3, T4 and T5 blocks respectively. These organic sources were added 
three weeks prior to sowing of filed beans. The Phosphorous (P) and Potassium (K) requirement for these blocks were balanced/ met through inorganic fertilizer application. For the treatment T2, RDF of 25:50:25 kg/ha was applied and there was no FYM, faecal sludge and co-compost application. Here, inorganic fertilizers like Urea, Single Super Phosphate (SSP) and Muriate of Potash (MOP) were added as basal dose per plot. The 5 treatment details are as summarized below:

T1: Absolute Control (No addition of organic manures or inorganic fertilizers)

T2: Recommended dose of fertilizer (RDN) - 25:50:25 kg/ha (Chemical fertilizers)

T3: RDN through faecal sludge + balance $\mathrm{P}$ and $\mathrm{K}$ through (*inorganic fertilizers)

T4: RDN through co-compost + balance $\mathrm{P}$ and $\mathrm{K}$ through (*inorganic fertilizers)

T5: RDN through FYM + balance P through (*inorganic fertilizers)

RDN: Recommended dose of nitrogen

*Inorganic fertilizers $=$ Urea $-46 \% \mathrm{~N}, \mathrm{SSP}=16 \% \mathrm{P} 2 \mathrm{O} 5, \mathrm{MOP}=60 \% \mathrm{~K} 2 \mathrm{O}$

The final co-compost sample which was one of the inputs for the trial was tested for physical, chemical and microbial parameters.

The objective of the field experiment was to assess the long-term implications of different treatments like faecal sludge, co-compost, farmyard manure and recommended dose of fertilizers (RDF) on crop growth and development and yield parameters. For each treatment, five plants were randomly selected $(5 \times 20=100$ plants in total). These plants were tagged and labelled with the treatment details. The field observations of growth and yield parameters are made for these tagged plants.

The plot wise yield data (KGs) of field beans for all the five treatments during nine harvests were collected and then the total yield was recorded. The growth and development parameters of field beans were collected 60 days after sowing. The data was collected from the randomly tagged five plants from each of the 20 plots.

A second crop was cultivated in the following Rabi season after the harvesting of field beans in the same field without altering the RBD. This was mainly to effectively utilize the residual moisture and nutrient content of the soil from the previous (Kharif) season. For this purpose, the root crop Sweet Potato was selected. Since Sweet Potato is a residual crop, treatments were not imposed again. The yield parameters of Sweet Potato like total root yield and weight of marketable and non-marketable roots were collected at the harvest phase. The field data for the growth parameters of Sweet potato like vine length and number of branches were collected from the tagged plants ( 5 plants per plot) and the results are plotted in the below graphs.

The edible part (field beans - pods, sweet potato - roots) of the produce after harvesting was analysed for pathogen contamination. The data from the field with regard to crop yield, growth and development was also recorded. The post-treatment data on yield parameters was collected at harvesting phase.

\section{RESULTS AND DISCUSSIONS}

\subsection{Co-compost characteristics}

The physical, chemical and microbial parameters and microbial parameters of co-compost are presented in Table 1. 
Table 1: Characteristics of mature co-compost.

\begin{tabular}{|l|c|c|}
\hline Parameters & FCO standards & $\begin{array}{c}\text { Final compost from } \\
\text { the windrow }\end{array}$ \\
\hline $\mathrm{pH}$ & $6.5-7.5$ & 6.51 \\
\hline Conductivity (dsm-1) & 8.2 & 0.9 \\
\hline Particle size & $\begin{array}{c}\text { Minimum 90\% material } \\
\text { should pass through } \\
4.0 \text { mm sieve }\end{array}$ & Passes \\
\hline $\begin{array}{l}\text { Moisture, percentage by weight, } \\
\text { minimum }\end{array}$ & 25 & 30.2 \\
\hline Bulk density & $<1.0$ & 0.77 \\
\hline $\begin{array}{l}\text { Total organic carbon, percent by } \\
\text { weight, minimum }\end{array}$ & 12 & 16.5 \\
\hline $\begin{array}{l}\text { Total N, percent by weight, } \\
\text { minimum }\end{array}$ & 0.8 & 0.7 \\
\hline Nitrate Nitrogen \% & $? ?$ & 0.23 \\
\hline $\begin{array}{l}\text { Total P (as P2O5), percentage by } \\
\text { weight, minimum }\end{array}$ & 0.4 & 0.24 \\
\hline $\begin{array}{l}\text { Total K (as K2O), percent by } \\
\text { weight, minimum }\end{array}$ & 0.4 & 0.98 \\
\hline C:N & $<20$ & 12.1 \\
\hline
\end{tabular}

Table 2: Presence of pathogen in co-compost.

\begin{tabular}{|l|l|l|}
\hline Pathogens & Compost standards & $\begin{array}{l}\text { Co-composted FS from } \\
\text { the windrow }\end{array}$ \\
\hline Helminth eggs & $\begin{array}{l}\leq 3-8 \text { eggs/gram of dry solids } \\
\text { (Source: Strauss, 1991 [3]) }\end{array}$ & Negative \\
\hline $\begin{array}{l}\text { Faecal coliforms } \\
\text { (MPN - Most } \\
\text { Probable Number) }\end{array}$ & $\begin{array}{l}<1000 \mathrm{MPN} / \mathrm{g} \text { (Source: CCME When } \\
\text { compost contains only yard waste) }\end{array}$ & $>1,600 \mathrm{MPN} / \mathrm{g}$ \\
\hline
\end{tabular}

As per the analysis, the final mature compost meets most of the FCO standards (Table 1) and is free from pathogen contamination (Table 2).

The final compost obtained from the windrow method of composting is able to maintain the nutrient balance $\mathrm{C}: \mathrm{N}$ ratio. Of all the excreted pathogen groups, representatives of helminth eggs are the most resistant and hence are often used as indicator organisms. The thermophilic phase of the composting ensures deactivation of these helminth eggs; pathogen die off at 60 degrees Celsius temperature. Preliminary research also suggests that some compost may have high faecal coliform counts due to bacteria of environmental origin and not of faecal origin. Thus, faecal coliforms may not be a reliable indicator of pathogen levels under all circumstances. The study also proposes to repeat the treatments with more number of samples/windrows to come to a definitive conclusion of the above study findings. 


\subsection{Results from application of soil conditioners}

\subsubsection{First crop: Kharif season - field beans}

The findings of the study from field experiments showed that the yield obtained from the crop (field experiment plots) grown under co-composted faecal sludge was comparatively higher than other treatments/nutrient sources (Fig. 5). The growth and development parameters like plant height, number of leaves, number of beans, weight of beans in grams, weight of bean seeds in grams etc. were slightly better for co-compost applied plots compared to other treatments (Fig. 6). The field beans final produce from all the five treatments was also sample tested for pathogen contamination. The results showed that the produce was free of E.coli and Faecal Coliforms.

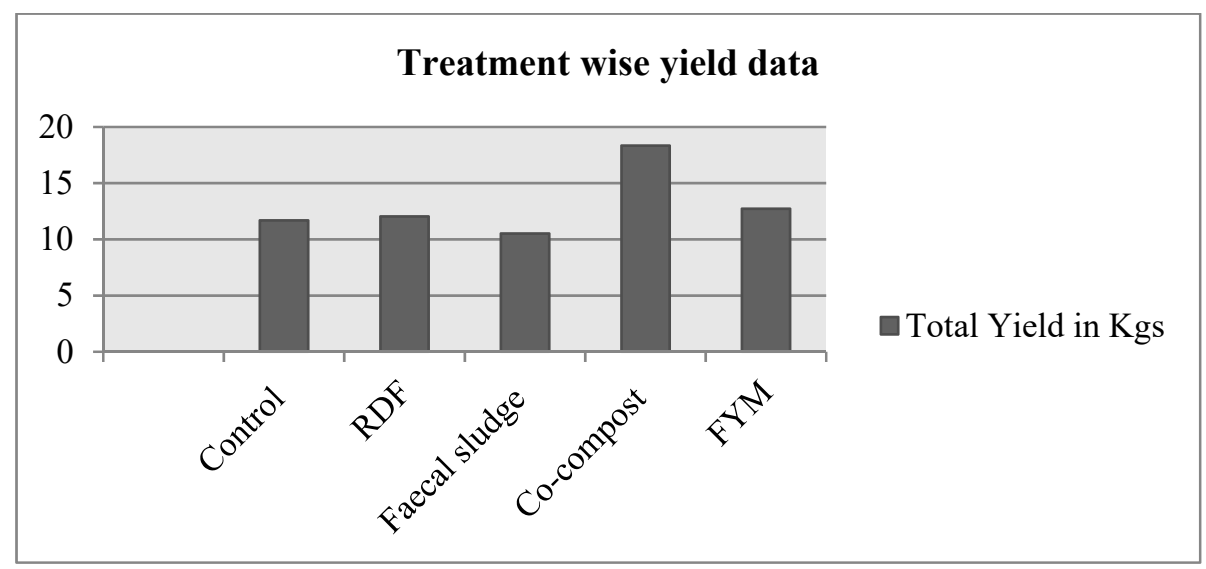

Figure 5: Treatment wise yield for field beans.

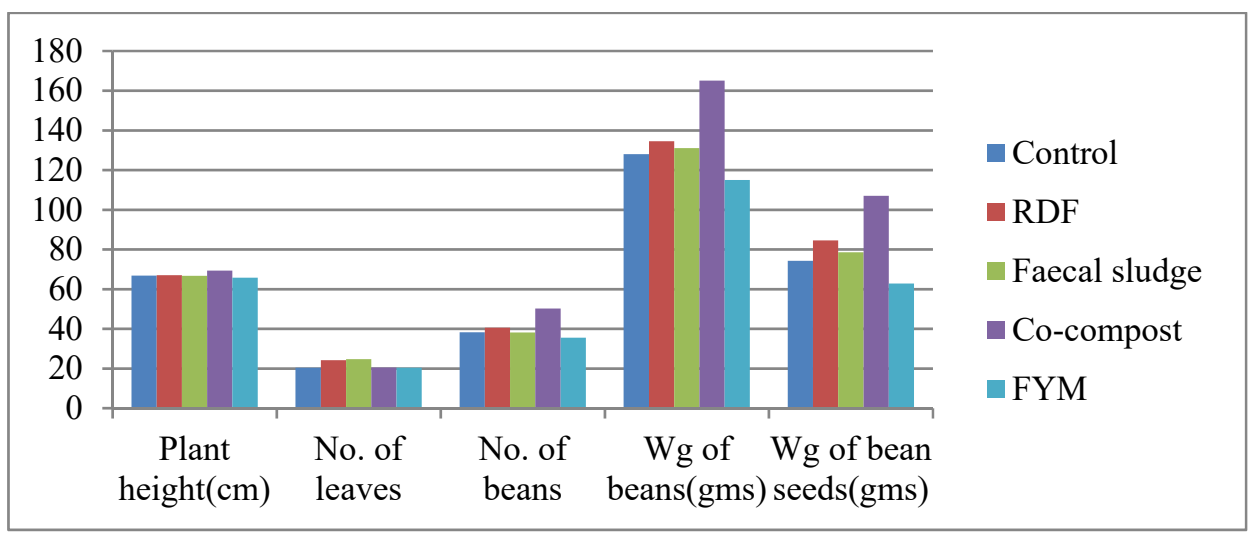

Figure 6: Treatment wise growth and development parameters for field beans.

The statistical analysis (ANOVA - One way) of the field results was conducted. The p-value was very close to the cutoff $(0.05)$. Findings showed that the differences in yield among different sources of nutrients were slightly significant ( $\mathrm{p}$-value $=0.0632$ ). The 
yield difference due to co-compost application was higher compared to other sources. But, the results for crop growth and development were not statistically significant.

\subsubsection{Second crop: Rabi season - Sweet potato}

The findings of the study from the field experiment showed that the sweet potato root yield and weight of marketable root obtained from the field experiment plots grown under co-composted faecal sludge was comparatively higher than other nutrient sources (Fig. 7). The growth and development parameters like vine length and number of branches etc. were slightly better for co-compost applied plots compared to other treatments (Fig. 8).

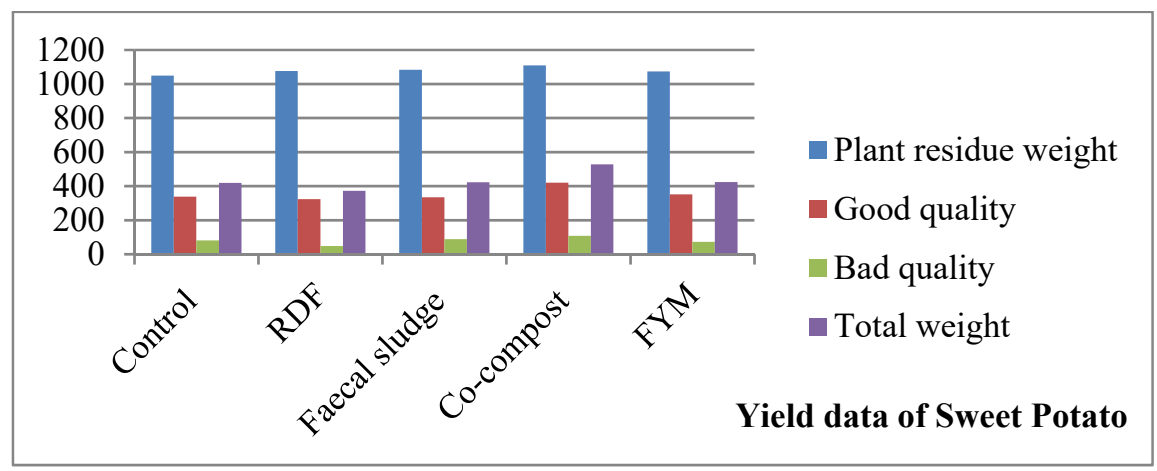

Figure 7: Treatment wise yield data of sweet potato.

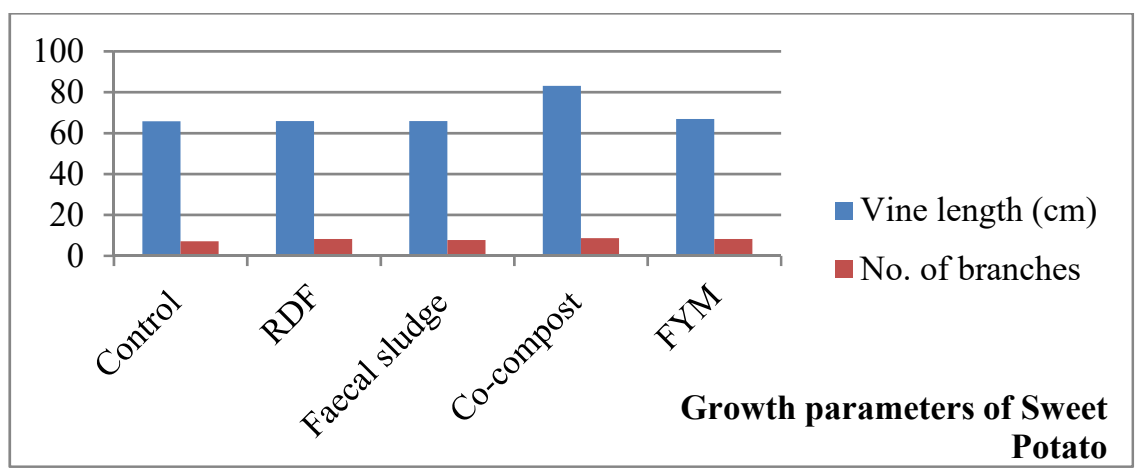

Figure 8: Treatment wise growth and development data of sweet potato.

The statistical analysis (ANOVA - One way) of the field results was conducted. The p-value was very close to the cutoff (0.05). Findings showed that the differences in yield among different sources of nutrients were slightly significant ( $p$-value $=0.0614$ ). The yield difference due to co-compost application was higher compared to other sources. But, the results for crop growth and development were not statistically significant. The Sweet Potato sample was also tested for pathogen contamination. The test report results showed negative for Helminths Egg presence both in the pulp part and the edible portion with skin. The study also proposes to repeat the field experiment for few more cropping seasons to come to a definitive conclusion of the above findings. 


\section{RECOMMENDATIONS AND CONCLUSIONS}

Co-composting of faecal sludge with municipal wet waste will result in nutrient rich manure for application in agriculture. Co-composting proves to be safe for reuse of humanure and reduces the pressure on depleting natural resources for nutrients. Many studies have been conducted in India and outside which explain and quantify pathogen reductions achievable by various health protection measures. But there are not many studies with regard to its implication on crop growth and yield parameters. The findings of this research have given us the base to promote the use of human excreta-based soil inputs as they increase crop growth and yield.

Reusing co-compost in agriculture will greatly benefit the farming community by enhancing soil productivity, thereby increasing crop production. These will, in turn, have significant economic benefits by reducing expenses on public health and environment protection. The following health protection measures at each level of operation will reduce the health risks while ensuring human safety. Closing the nutrient loop by reusing human waste in food production has great potential in addressing sanitation and agriculture issues. Considering the nutrient significance of humanure and its role in combating the negative impact on the environment and public health (by reducing unsafe dumping on land and in waterbodies), human excreta-based soil inputs should be promoted for application in agriculture.

The need of the hour is to promote humanure application on the lines of city compost marketing. So that it would encourage famers to use humanure in agriculture. Below are some of the recommendations from the study:

- Acknowledging the unsafe faecal sludge disposal problem and promote the reuse of human excreta-based soil inputs

- There is a need to take measures to popularise humanure by providing direct incentives or subsidies on use of co-compost to farmers. The available assistance (subsidy) on the sale of compost from municipal solid waste should be considered for the sale of humanure also

- Marketing Development Assistance for the direct sale of humanure by compost manufacturers to farmers will make it more economical

- Humanure should also be co-marketed by tagging of cities with fertilizer marketing companies

\section{ACKNOWLEDGEMENTS}

This study was supported by Consortium for DEWATS (Decentralised Wastewater Treatment System) Dissemination Society, Bengaluru, University of Agricultural Sciences, Bengaluru and Town Municipal Council, Devanahalli, Bengaluru, and their support is gratefully acknowledged.

\section{REFERENCES}

[1] Patra, S., Mishra, P., Mahapatra, S. \& Mithun, S., Modelling impacts of chemical fertilizer on agricultural production: A case study on Hooghly district, West Bengal, India. Modeling Earth Systems and Environment, 2(4), pp. 1-11, 2016.

[2] Bünemann, E. et al., Soil quality: A critical review. Soil Biology and Biochemistry, 120, pp. 105-125, 2018.

[3] Strauss, M., Human waste use: Health protection practices and scheme monitoring. Water Science and Technology, 24(9), pp. 67-79, 1991. 
[4] Avvannavar, S. \& Mani, M., Guidelines for the safe use of wastewater, excreta and greywater, Volume 3: Wastewater and excreta use in aquaculture, 2006, WHO, 20. Science of the Total Environment, 382(2-3), pp. 391-392, 2007.

[5] Victor, R., Kotter, R., O’Brien, G., Mitropoulos, M. \& Panayi, G., WHO Guidelines for the safe use of wastewater, excreta and greywater, Volumes 1-4. International Journal of Environmental Studies, 65(1), pp. 157-176, 2008.

[6] Yeboah Siaw, J., Occupational health and safety status in the management of faecal sludge in Ghana: A case study of the Lavender Hill Faecal Treatment Plant. Journal of Health and Environmental Research, 4(2), p. 42, 2018.

[7] Jiménez, B., Maya, C., Barrios, J. \& Navarro, I., Helminths and their Role in Environmental Engineering. Human Helminthiasis, pp. 5-6, 2017.

[8] Cofie, O., Kone, D., Rothenberger, S., Moser, D. \& Zubruegg, C., Co-composting of faecal sludge and organic solid waste for agriculture: Process dynamics. Water Research, 43(18), pp. 4665-4675, 2009.

[9] Koné, D. et al., Helminth eggs inactivation efficiency by faecal sludge dewatering and co-composting in tropical climates. Water Research, 41(19), pp. 4397-4402, 2007.

[10] Douglas, C.M., Experiments with Blocking Factors. Design and Analysis of Experiments, Wiley, pp. 139-141, 2009. 